\title{
CONSUMPTION HABITS AND INTEREST RATE RIGIDITY
}

\author{
Wilfredo L. MALdonado* \\ Catholic University of Brasilia \\ Augusto M. De C. Oliveira** \\ Catholic University of Brasilia
}

Submitted August 2010; accepted March 2011

\begin{abstract}
In this paper we provide a micro model of loans which the lender is a monopolistic bank and the borrower is a competitive consumer with consumption habits who may default on part of his debt. In this setting, we prove that the loan demand curve is kinked and therefore it is possible to find interest rate rigidity in equilibrium as well as asymmetric response of loans to interest rate variations. Finally, we show through an example that the credit supply, as a function of the marginal cost of the bank, exhibits a discontinuity on that marginal cost. As a consequence, lowering the basic interest rate of the economy may produce a sudden increase in credit demand/supply and in the default on debts.
\end{abstract}

\section{JEL classification codes: E43, D01}

Keywords: interest rate rigidity, kinked Loan demand, consumption habits

\section{Resumo}

Neste artigo proporcionamos um modelo microeconômico de empréstimos, em que o cedente do empréstimo é um banco monopolista e o tomador do empréstimo é um consumidor competitivo com hábitos no consumo que pode não honrar os seus compromissos de crédito em parte ou totalmente. Neste cenário, provamos que a curva de demanda por empréstimos é quebrada e, portanto, é possível encontrar rigidez da taxa de juros em equilíbrio, assim como resposta assimétrica da demanda por empréstimos a variações da taxa de juros. Finalmente, mostramos através de um exemplo que a oferta de crédito, como função do custo marginal do banco, exibe uma descontinuidade nesse custo marginal. Como consequência, diminuições na taxa básica da economia podem produzir um súbito aumento na demanda/ oferta de crédito e na inadimplência.

\section{Palavras-Chave}

rigidez da taxa de juros, demanda quebrada por empréstimos, hábitos no consumo

\footnotetext{
* Graduate School in Economics - Catholic University of Brasília - Corresponding Author: Catholic University of Brasília, SGAN 916 - MóduloB, WS Norte - Asa Norte - Brasília DF. BRAZIL - CEP: 70790-160 - E-mail: wilfredo@pos.ucb.br - Wilfredo Maldonado would like to thank the financial support provided by CNPq (Brazil) through grants 304844/2009-8 and 401461/2009-2.

** Graduate School in Economics - Catholic University of Brasília - Corresponding Author: Catholic University of Brasília - SGAN 916 - Módulo B, WS Norte - Asa Norte - Brasília DF. BRAZIL - CEP: 70790160 - E-mail: augusto.castro-oliveira@itau-unibanco.com.br - Augusto Oliveira would like to acknowledge the financial support of ITAU-UNIBANCO to accomplish this research.

The authors thank the valuable comments and suggestions of the anonymous referee.
} 


\section{Introduction}

One of the main concerns in applied and theoretical economics is the absence or slow response of some economic variables to shocks in fundamentals or in economic policy instruments. New Keynesian models suppose that agents have delays in some decisions and that they generate rigidity or sticky prices. In that vein, some works evaluate the impact of monetary policies on inflation and growth, supposing that some firms do not update prices after shocks in costs or other relevant variables (Calvo 1983, Rotemberg; Woodford 1997 and 1998).

An alternative to sticky prices, provided by Mankiw and Reis (2001) and Keen (2007), is the assumption of sticky information, which is caused by costs in collecting new information or in re-executing optimization processes. Industrial Organization theory provides another explanation for price rigidity: the stickiness in prices results from collusive behavior among firms. Empirical and econometric analyses were performed to conclude that market concentration is responsible for that phenomenon (Mills 1927, Means 1935, Carlton 1986 and 1989). On the theoretical side, the most popular theory to explain rigidity is the "kinked demand" (Sweezy 1939 and Hall; Hitch 1939); however, Scherer (1980) and Tirole (1988) highlight some important shortcomings of that theory. Implicit or explicit collusions are also included as a theoretical explanation for rigidity (Athey; Bagwell; Sanchirico 2004).

In credit markets, empirical studies report not only rigidity in the interest rates but also asymmetric response of them with respect to costs variations or shocks in interest rates of funds. Hannan and Berger (1991) analyzed monthly data of 398 American banks in the period September 1983 to December 1986 and argued that the deposit rate rigidity is a result of either the market concentration or the size of the consumer base. Using a multinomial logit model they analyzed the asymmetric response of interest rate in relation to increases or decreases in the security-rate. Neumark and Sharpe (1992) show that banking concentration is responsible for the asymmetric adjustment of the deposit rates. To this end, they use monthly data of a survey conducted by the Federal Reserve Board on the yield behavior of two types of deposits: the six-month certificate of deposit and money market deposit account. They consider a sample of 255 banks located in 105 Metropolitan Statistical Areas in the USA over the period October 1983 to November 1987 to accomplish a panel data analysis that allows concluding that asymmetric adjustment. Scholnick (1996) examined the difference between the upward and downward rigidity of the retail interest rate using co-integration and error correction methodology. The analysis was made for the banking systems of Malaysia and Singapore after their financial liberalizations occurred in 1978. 
In Brazil it is quite interesting the presence of the rigidity of the market interest rate. In Figure 1 we show the values of the SELIC interest rate (which is the reference interest rate for the Government debt) versus the interest rate paid by consumers from 1994 to 2009 (given in monthly percentages). That is the interest rate of credit with nonearmarked resources offered to individuals (Central Bank of Brazil, BCB - DEPEC). Using that data we adjust two linear regressions between those variables, one for SELIC values lower than $3.3 \%$ and another for values greater than $3.3 \%$. We can observe that for a SELIC greater than $3.3 \%$ the consumer interest rate remains almost unaltered, thus changes in the interest rate paid by the Government when it is greater than $3.3 \%$ per month does not affect the market interest rate paid by the consumers.

\section{Figure 1 - SELIC vs. Consumer Interest Rate}

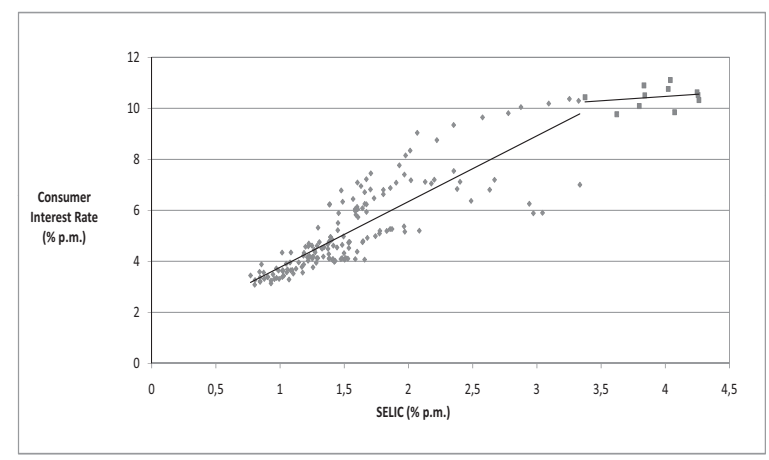

Source: Central Bank of Brazil - DEPEC.

The purpose of this paper is to provide a theoretical framework where interest rate rigidity arises due to the existence of consumption habits of the borrowers. More precisely, shocks in the marginal costs of the bank affect neither the market interest rate nor the amount of loans taking by the borrowers. To obtain this, we consider a partial equilibrium model, where the borrowers may default in part on their debts and they do this indeed, in order to preserve the consumption in a previous period (consumption habit formation). As a consequence, they accept to pay higher interest rates even though the marginal cost of the bank might be reduced. Furthermore the response of the loan demand is asymmetric to increases or decreases of the market interest rate. Therefore, not only may the banking industry concentration provoke the rigidity, but also the demand side may, when individuals want to preserve the status quo in their consumptions. In addition, using the same loan market model, we verify, through a simple example, the existence of a discontinuity in the demand/supply of credit as a function of the marginal cost of the bank. In particular, it implies that successive decreases of the basic interest 
rate of the economy (which is part of the marginal cost) may provoke a sudden increase in the amount of credit and in the default on debts. This is a counter-productive effect if the monetary authority aims to reduce the basic interest rate without producing inflation or an increase in the default rate on debts.

Consumption habits and their consequences have been extensively studied in economics. Using information included in the Panel Study on Income Dynamics, Dynan (2000) tests the presence of consumption habits in the USA economy and asserts that the same may explain the excess of smoothness in the aggregate consumption. That data consider information about annual income, employment and demographic characteristics of 3.153 households from 1974 to 1987. In another work, using USA quarterly data of consumption, price levels, federal fund rates, disposable personal income and GDP (excluding non-durable goods and services) from 1966:I to 1995:IV, Fuhrer (2000) also tests and rejects the hypothesis of no habit formation in consumption in a monetarypolicy model. In order to explain the strong correlation between saving and growth, Carroll, Overland and Weil (2000) provide a dynamic model where individuals exhibit consumption habits. They show that classical models with standard consumer utility functions are unable to explain such a correlation because forward-looking households save less in a fast-growing economy since they will be richer in the future than they are today.

The paper is divided in the following way: in section II we present our theoretical framework; section III is devoted to presenting the results: the asymmetric response of the loan demand and the rigidity of the interest rate. At the end of that section we provide an example showing the discontinuity of the demand/supply of credit in the marginal cost of the bank; section IV presents the conclusions and the proofs are shown in the Appendix.

\section{The Model}

We will consider a loan market model with a large number of borrowers represented by a single agent and a lender represented by a monopolistic bank. The idea is to model borrowers are interest-rate-takers in the loan market and lenders that have market power to decide the interest rate, so this framework is the simplest one to attain this goal. In addition, if there exists a small number of banks, some collusive behavior among them may lead the bank system to act as a monopolistic bank. There are two periods $t=0,1$ and in $t=0$ the borrower demands loans $(m)$ and consumption $\left(c_{0}\right)$. In $t=1$, the same agent delivers (part of) the debt and also consumes $\left(c_{1}\right)$. In case the borrower does not fulfill his entire obligation, he will suffer a penalty in his utility function. The interest rate on loans is given by $r>0$. 
All these elements are included in the classic models with possibility of default (Dubey; Geanakoplos; Shubik 2005). In this work we consider an additional term representing the consumption habits of the borrower. If in the second period, the consumption is greater or equal to that of the first period, the agent does not suffer any loss in his utility. Otherwise, he will have a disutility proportional to the consumption decrease. Namely, the payoff of the borrower with consumption plan $\left(c_{0}, c_{1}\right) \in R_{+}^{2}$, loan demand $m \geq 0$ and delivery decision $D \in[0,(1+r) m]$ is given by:

$V\left(c_{0}, c_{1}, m, D\right)=U\left(c_{0}, c_{1}\right)-\lambda[(1+r) m-D]-\gamma \operatorname{Max}\left\{c_{0}-c_{1}, 0\right\}$

The parameters $\lambda>0$ and $\gamma>0$ in (1) represent the intensity of the penalty for defaulting and the disutility for the decrease in the first period consumption due to the consumption habits, respectively. Notice that the last term in (1) is an extra term included to show the willingness to maintain the status quo in consumption relative to the first period consumption. If the consumer increases his consumption in the second period, the only benefit is already computed in the utility function $U$. However, if the consumption is reduced, not only does the utility function $U$ include the loss of that reduction, but there is another negative effect represented in the last term of equation (1). In infinite horizon models, the influence of the habit formation in consumption is measured as a penalty in deviations from the average consumption in a predetermined past period (see Campbell; L0; Mackinlay). In a two-period setting we find our representation as a quite reasonable simplification. We will suppose separability and Inada conditions in preferences, as stated in the following assumption:

Hypothesis (H): The utility function of consumption is a separable function $U\left(c_{0}, c_{1}\right)=u\left(c_{0}\right)+\delta u\left(c_{1}\right)$; where $u: R_{+} \rightarrow R$ is twice differentiable, $u^{\prime}>0, u^{\prime \prime}<0$ and satisfies $u^{\prime}(0)=+\infty, u^{\prime}(+\infty)=0$.

Finally, if $p_{0}>0$ and $p_{1}>0$ are the commodity prices of goods and $w_{0}>0$ and $w_{1}>0$ are the initial endowments in periods $t=0,1$ respectively, then the budget constrain for the representative agent is defined by the following inequalities:

$$
\begin{aligned}
& p_{0} c_{0} \leq p_{0} w_{0}+m \\
& p_{1} c_{1}+D \leq p_{1} w_{1} \\
& 0 \leq D \leq(1+r) m
\end{aligned}
$$


In this way, the borrower problem is defined as the maximization of the payoff function (1) in variables $c_{0}, c_{1}, m$ and $D$ subject to the restrictions (2), (3) and (4). The demand for loans is the $m^{*}=m(r)$ component of the solution of that problem.

In this economy, the lender side is modeled by a monopolistic bank which decides the value of the interest rate $r>0$ to be fixed for private loans, given the loan demand curve $m=m(r)$. The assumption of a monopoly in the loan market may be seen as a simplification of a collusive behavior of an oligopoly in that sector. Thus, if $c(m)$ is the cost of the monopolist, its problem is to choose the interest rate for loans in order to maximize $R(m)-c(m)=(1+r) m(r)-c(m(r))$.

\section{Asymmetry of the Loan Demand and Rigidity of the Interest Rate}

In this section we will prove the asymmetry of the loan demand response to changes in the interest rate (a kinked demand curve for loans). As a consequence, the marginal revenue of the monopolist will present a discontinuity provoking rigidity in the interest rate with respect to marginal costs changes of the monopolist. In the literature the discontinuity of the marginal revenue (and therefore the rigidity of prices) is found as a consequence of some kind of oligopolistic competition among firms (Sweezy 1939 and Hall; Hitch 1939). In our case, the kinked demand results from the endeavor of borrowers to maintain the status quo in their consumptions.

The following proposition states the existence of (at most) two kinks in the demand for loans.

Proposition 1. (Asymmetry of the response to interest rate changes) Under hypothesis (H) the loan demand curve $m=m(r)$ is strictly decreasing and there exist two values of the interest rate:

$$
r_{1}=\frac{p_{1}}{\delta p_{0}}-\frac{\gamma}{\lambda p_{0}}\left(1+\frac{1}{\delta}\right)-1 \quad \text { and } \quad r_{2}=\frac{p_{1}}{\delta p_{0}}-1
$$

where the demand for loans is kinked. In other words:

$$
\lim _{r \rightarrow r_{i}^{+}} m^{\prime}(r) \neq \lim _{r \rightarrow r_{i}^{-}} m^{\prime}(r) ; i=1,2
$$

The proposition above implies the shape shown in Figure 2 for the loan demand. Note that $r_{1}<r_{2}$, and if we have in addition that $\delta=(1+\rho)^{-1}, p_{1} / p_{0}=1+\pi(\rho>0$ is the intertemporal discount rate and $\pi>0$ is the inflation rate) then $r_{2}>0$. Therefore if $r_{1}>0$ then we will 
have two kinks in the demand curve for loans; otherwise there will be just one. In each kink it is easy to verify the asymmetric response of demands for loans with respect to interest rate changes.

It is also worth noting that the difference $r_{2}-r_{1}=\gamma /\left(\lambda p_{0}\right)$ depends on the intensity of the consumption habits. Furthermore, from the proof of Proposition 1, we can conclude that $\gamma=0$ implies the non-existence of any kink in the loan demand curve, therefore, for this type of models, habit formation is a necessary and sufficient condition for obtaining kinked demand.

Figure 2 - Demand for Loans under Consumption Habits and the Asymmetric Response to Interest Rate Changes

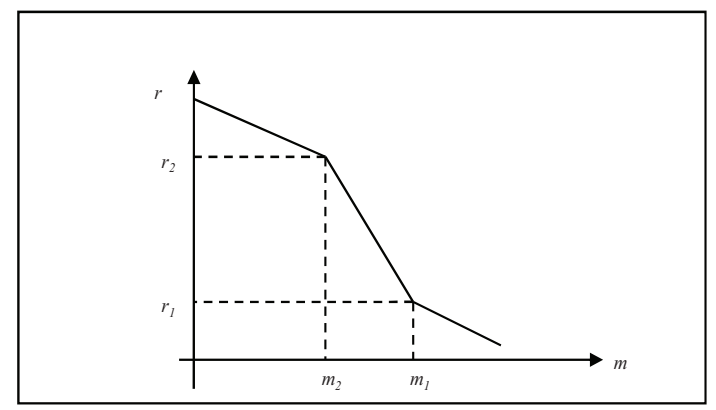

If we suppose that the marginal cost of the monopolistic bank is a constant $(M C=c)$ then we will have the following result.

Proposition 2. (Rigidity of the interest rate) Under hypothesis $(\mathrm{H})$ and the assumption of constant marginal costs of the monopolist bank $(M C=c)$, there exist two open intervals $I_{1}$ and $I_{2}$ such that: a) for all $c \in I_{2}$, the equilibrium interest rate is $r_{2}$, b) for all $c \in I_{1}, r_{1}$ is a relative minimum of the profit and the equilibrium interest rate is located around that minimum.

Proposition 2 asserts that any change in the marginal cost that leaves it in the interval $I_{2}$ will not have effect on the equilibrium interest rate which will remain in $r_{2}$ (and as a consequence, the loan demand will remain equal to $m_{2}$ ), this is the rigidity of the interest rate. Figure 3 shows the shape of the marginal revenue and one possible position of the marginal cost where we obtain the rigidity.

If in addition, the monopolistic bank finances the Government debt too; we can obtain an important conclusion from the rigidity of the market interest rate with respect to 
changes in the interest rate paid by the Government. Let $r_{f}>0$ be the interest rate on the Government loans (risk-free interest rate). If $M$ is the total amount of resources available to the bank to lend either to the borrowers or to the Government, the problem of the lender results:

$\operatorname{Max}_{m \geq 0}(1+r(m)) m+\left(1+r_{f}\right)(M-m)-c m=\operatorname{Max}_{m \geq 0}(1+r(m)) m-\left(c+1+r_{f}\right) m$,

\section{Figure 3: The Marginal Revenue of the Monopolistic Bank}

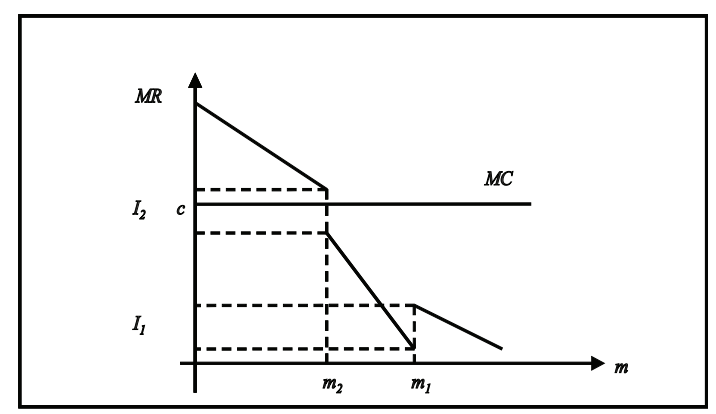

therefore any change in $r_{f}$ that leaves $c+1+r_{f}$ in the interval $I_{2}$ affects neither the equilibrium interest rate nor the amount of loans, which remain in $r_{2}$ and $m_{2}$ respectively.

\section{A Numerical Example}

In order to illustrate the main result of the paper, we provide the following example. It will also allow us to show how sequential marginal cost reductions may provoke a sudden increase in the loans amount. Let us consider $u(c)=b c-c^{2} / 2$, where $b>0$ and suppose $w_{0}=0, w_{1}=3.2,{ }^{1} p_{0}=1$ and $p_{1}=1+\pi$. The demand for loans is given by:

$$
m(r)=\left\{\begin{array}{cc}
(b-\gamma-\lambda)-\lambda r ; & \text { if } r<r_{1} \\
(b-\lambda)-\lambda r ; & \text { if } r>r_{2} \\
\left(b-\lambda(2+\pi)(1+\delta)^{-1}\right)-\lambda(1+\delta)^{-1} r ; & \text { if } r_{1} \leq r \leq r_{2}
\end{array}\right.
$$

${ }^{1}$ This value allows us to consider market interest rates in the interval $[0,0.4]$ and as a consequence, the solution of the borrower problem is interior with respect to the restriction $0 \leq D \leq(1+r) m$. 
where $r_{1}$ and $r_{2}$ are defined in Proposition 1. Let us consider the following parameter values: $b=15 ; \gamma=1 ; \lambda=10 ; \pi=0.05 ; \delta=0.8$. With these values we obtain $\left(r_{1}, m_{1}\right)=(0.0875,3.125)$ and $\left(r_{2}, m_{2}\right)=(0.3125,1.875)$. The intervals given in Figure 3 are $I_{1}=[0.525,0.775]$ and $I_{2}=[0.975,1.125]$. Then, for any value of the marginal cost contained in $I_{2}$, the market interest rate remains invariant and equal to $r_{2}=0.3125$. This is the rigidity of the interest rate. In addition, we would like to comment on another remarkable effect of the model. If the marginal cost belongs to the interval $I_{1}$, the profit of the monopolist will exhibit two relative maximums. Figure 4 depicts the profits for three values of the marginal cost.

Figure 4: The Monopolist Profit for three Marginal Costs

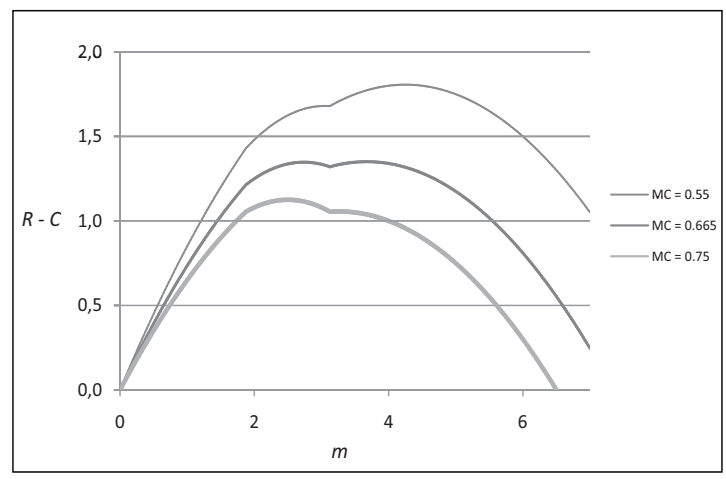

As we can observe, reductions in the marginal cost provoke a jump (discontinuity) in the total amount of credit supply. Figure 5 shows the discontinuity of the equilibrium loan amount $(m(c))$ with respect to the marginal cost of the monopolist $(c)$.

Figure 5 - Discontinuity of the Equilibrium Loan Amount with Respect to the Marginal Cost of the Monopolist

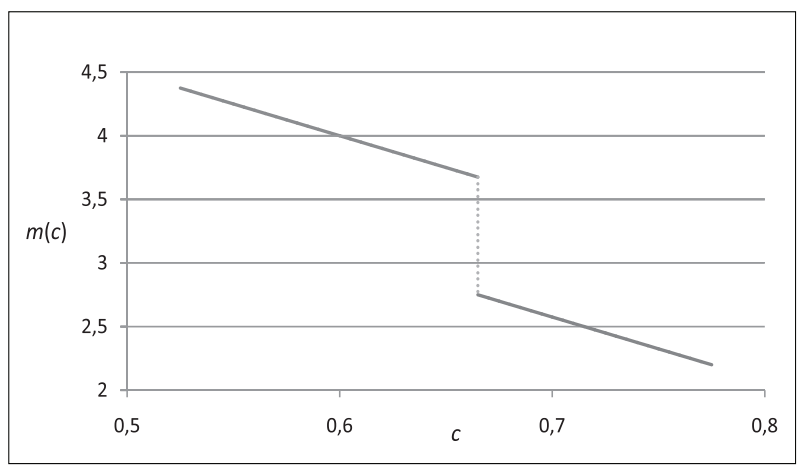


The explanation for this effect is the following. Reductions in the marginal cost provoke reductions in the market interest rate, so individuals pass from region $c_{0}=c_{1}$ to region $c_{0}>c_{1}$. This is done by augmenting both consumptions, taking more credit in the first period and delivering a lower part of the debt. This is an important effect that monetary authorities must take into account in the process of reducing the basic interest rate of the economy. There is a threshold value for this interest rate from which agents significantly increase the credit demand, the current and the future consumption and the default. If the objective is to reduce the interest rate without provoking inflation (due to the increase in consumption) or increasing the default on debts, the authority has to consider this perverse effect.

\section{Conclusions}

In this paper we provided an explanation of the asymmetry of the loan demand response to changes in the interest rate. The kinked demand for loans that provokes that effect is a result of the borrowers' willingness to maintain the status quo in their former consumptions. As a consequence, the marginal revenue of the monopolistic bank presents a discontinuity, generating rigidity of both the interest rate and loans with respect to changes in its marginal cost. This kind of consumption habit was not used to explain phenomena of asymmetry and rigidity in the literature, so it provides another explanation that may complement the theories of sticky prices based on concentration or collusion of firms in specific markets.

Using the same model, we show that the amount of loans may have a sudden increase when the marginal cost of the monopolist is reduced. The low penalty for defaulting on a small debt (due to the small market interest rate) allows increasing consumption in both periods (taking out more loans in the first period and delivering a lower part of the debt in the second period).

From the monetary policy point of view, both effects described in the paper (the rigidity of the interest rate and the discontinuity in the amount of credit) are market imperfections that policy-makers must take into consideration. This is because, as we noted in the comments of section III, it is possible that the monetary policy instrument (the interest rate paid by the Government on its loans), might not be effective (if it falls into the region of interest rate rigidity) or even provoke a sudden increase in inflation and increase in the default on debts. 


\section{References}

Athey, S., Bagwell, K., Sanchirico, C.H. (2004), Collusion and Price Rigidity. Review of Economic Studies, v. 71, p. 317-349.

Calvo, G. (1983), Staggered Prices in a Utility-Maximization Framework. Journal of Monetary Economics, v. 12, n. 3, p. 383-398.

Campbell, J., Lo, A., Mackinlay, A. (1997), The Econometrics of Financial Markets. Princeton University Press, Princeton.

Carlton, D. W. (1986), The Rigidity of Prices. The American Economic Review, v. 76, n. 4, p. 637-658.

Carlton, D. W. (1989), The Theory and The Fact of How Markets Clear: Is Industrial Organization Valuable for Understanding Macroeconomics? Handbook of Industrial Organization (R. Schmalensee and R. D. Willig Eds.), v. 1, p. 909-946.

Carroll, C. D., Overland, J., Weil, D. N. (2000), Saving and Growth with habit Formation. The American Economic Review, v. 90, p. 341-355.

Dubey, P., Geanakoplos, J., Shubik, M. (2005), Default and punishment in general equilibrium. Econometrica, v. 73, n. 1 , p. $1-37$.

Dynan, K. (2000), Habit formation in consumer preferences: Evidence from panel data. The American Economic Review, v. 90, n. 3, p. 391-406.

Fuhrer, J. (2000), Habit formation in consumption and its implications for monetary-policy models. The American Economic Review, v. 90, n. 3, p. 367-390.

Hall, R. L., Hitch, C. J. (1939), Price Theory and Business Behavior. Oxford Economic Papers, v. 2, p. 12-45.

Hannan, T., Berger, A. (1991), The rigidity of prices, evidence from the banking industry. The American Economic Review, v. 81, n. 4, p. 938-945.

Keen, B. (2007), Sticky price and sticky information price-setting models: what is the difference? Economic Inquire, v. 45 , n. 4 , p. $770-786$.

Mankiw, N. G., Reis, R. (2002), Sticky information versus sticky prices: A proposal to replace the New Keynesian Philip curve, The Quarterly Journal of Economics, v. 107, p. 1295-1328.

Means, G. (1935), Industrial Prices and Their Relative Inflexibility. Senate Document 13, 74th Congress, 1st Session (Washington D.C.).

Mills, F. C. (1927), The Behavior of Prices. NBER New York.

Neumark, D., Sharpe, S. (1992), Market Structure and the Nature of Price Rigidity: Evidence from the Market for Consumer Deposits. The Quarterly Journal of Economics, v. 107, n. 2, p. 675-680.

Rotemberg, J., Woodford, M. (1997), An Optimization-Based Econometric Framework for the Evaluation of Monetary Policy. NBER Macroeconomics Annual, 297-345.

Rotemberg, J., Woodford, M. (1998), Interest-rate rules in an estimated sticky price model, NBER Working Paper 6618.

Sherer, F. M. (1980), Industrial Market Structure and Economic Performance, 2nd Edition, Chicago: Rand McNally.

Scholnick, B. (1996), Retail interest rate rigidity after financial liberalization, The Canadian Journal of Economics, v. 29, n. 2, p. S433-S437.

Sweezy, P. M. (1939), Demand under conditions of oligopoly, Journal of Political Economy, v. 47, n. 4, p. 568-573.

Tirole, J. (1988), The Theory of Industrial Organization, Cambridge, MA and London: MIT Press.

\section{APPENDIX}

Proof of Proposition 1. The borrower problem is to maximize (1) restricted to the budget set:

$B\left(p_{0}, p_{1}, r\right)=\left\{\left(c_{0}, c_{1}, m, D\right) \in R_{+}^{4} /(2),(3)\right.$ and (4) are satisfied and $\left.m \leq v\right\}$. 
We are imposing bounded short-sales in order to guarantee finite solutions. Let $m^{*}=m(r)$ be the loan demand, which is (upper hemi-) continuous in $r>0$. The behavior of that solution will be described from a comparative static analysis, so interior solutions $m^{*}>0$ and $0<D^{*}<(1+r) m^{*}$ will be supposed. Since the payoff function depends on the signal of $c_{0}-c_{1}=-\Delta w+\left(m / p_{0}\right)+\left(D / p_{1}\right)$ (where $\left.\Delta w=w_{1}-w_{0}\right)$, we will separate the analysis into three cases:

Case I) $\frac{m}{p_{0}}+\frac{D}{p_{1}}>\Delta w$

In this case, the first order conditions are given by:

$$
\begin{aligned}
& u^{\prime}\left(w_{0}+\frac{m}{p_{0}}\right)=\lambda p_{0}(1+r)+\gamma \\
& u^{\prime}\left(w_{1}-\frac{D}{p_{1}}\right)=\frac{\lambda}{\delta} p_{1}-\frac{\gamma}{\delta}
\end{aligned}
$$

From (A1) and (A2) we can find:

$$
m(r)=p_{0}\left[\left(u^{\prime}\right)^{-1}\left(\lambda p_{0}(1+r)+\gamma\right)-w_{0}\right] \text { and } D(r)=p_{1}\left[w_{1}-\left(u^{\prime}\right)^{-1}\left(\delta^{-1}\left(\lambda p_{1}-\gamma\right)\right)\right]
$$

Whenever necessary, we will denote the demand for loans in this case by $m^{I}(r)$.

In order to compatibilize with $\frac{m(r)}{p_{0}}+\frac{D(r)}{p_{1}}>\Delta w$, we must have:

$$
\begin{aligned}
& \left(u^{\prime}\right)^{-1}\left(\lambda p_{0}(1+r)+\gamma\right)>\left(u^{\prime}\right)^{-1}\left(\delta^{-1}\left(\lambda p_{1}-\gamma\right)\right) \\
& \Rightarrow r<\frac{p_{1}}{\delta p_{0}}-\frac{\gamma}{\lambda p_{0}}\left(1+\frac{1}{\delta}\right)-1=r_{1}
\end{aligned}
$$

Case II) $\frac{m}{p_{0}}+\frac{D}{p_{1}}<\Delta w$

The first order conditions are:

$$
u^{\prime}\left(w_{0}+\frac{m}{p_{0}}\right)=\lambda p_{0}(1+r)+\gamma
$$


$u^{\prime}\left(w_{1}-\frac{D}{p_{1}}\right)=\frac{\lambda}{\delta} p_{1}$

From equations (A3) and (A4), the loan demand and delivery decisions are $m(r)=p_{0}\left[\left(u^{\prime}\right)^{-1}\left(\lambda p_{0}(1+r)\right)-w_{0}\right]$ and $p_{1}\left[w_{1}-\left(u^{\prime}\right)^{-1}\left(\delta^{-1} \lambda p_{1}\right)\right]$ respectively. In this case, the loan demand is denoted by $m^{I I}(r)$.

As in case I, the restriction $\frac{m(r)}{p_{0}}+\frac{D(r)}{p_{1}}<\Delta w$ implies the following demand for the
interest rate: $r>\frac{p_{1}}{\delta p_{0}}-1=r_{2}$

Case III) $\frac{m}{p_{0}}+\frac{D}{p_{1}}=\Delta w$

Since a solution exists for all $r>0$, this case will correspond to the domain $r \in\left(r_{1}, r_{2}\right)$. The first order condition is:

$$
\begin{aligned}
& \frac{u^{\prime}\left(w_{0}+m / p_{0}\right)}{p_{0}}+\delta \frac{u^{\prime}\left(w_{1}-D / p_{1}\right)}{p_{0}}=\lambda\left[(1+r)+\frac{p_{1}}{p_{0}}\right] \\
& \Rightarrow u^{\prime}\left(w_{0}+\frac{m}{p_{0}}\right)=(1+\delta)^{-1} \lambda\left[(1+r) p_{0}+p_{1}\right]
\end{aligned}
$$

From (A5) we obtain $m(r)=p_{0}\left[\left(u^{\prime}\right)^{-1}\left((1+\delta)^{-1} \lambda p_{0}(1+r)+(1+\delta)^{-1} \lambda p_{1}\right)-w_{0}\right]$ and the restriction of this case implies $D(r)=p_{1} \Delta w-\left(p_{1} / p_{0}\right) m(r)$. As done formerly, we denote the demand for loans here by $m^{I I I}(r)$. From (A1), (A3) and (A5) one can verify that the function $m=m(r)$ is a strictly decreasing function. Furthermore, the following limit exists, $\lim _{r \rightarrow r_{i}} m(r)=m_{i}=m\left(r_{i}\right) ; \quad i=1,2$

To prove the non-differentiability of $m(r)$ in $r_{i}$, we use equations (A1), (A3) and (A5) to calculate the derivatives in each interval, namely:

if $r<r_{1}$, then (A1) implies: $\frac{d m^{I}}{d r}(r)=\frac{\lambda p_{0}^{2}}{u \text { " }\left(c_{0}\right)}$;

if $r>r_{2}$, then (A2) implies: $\frac{d m^{I I}}{d r}(r)=\frac{\lambda p_{0}^{2}}{u^{\prime \prime}\left(c_{0}\right)}$; 
if $r \in\left(r_{1}, r_{2}\right)$, then (A3) implies: $\frac{d m^{I I I}}{d r}(r)=\frac{(1+\delta)^{-1} \lambda p_{0}^{2}}{u^{\prime \prime}\left(c_{0}\right)}$,

where $c_{0}=w_{0}+m(r) / p_{0}$. Therefore, we can conclude that,

$\lim _{r \rightarrow r_{1}^{-}} m^{\prime}(r)<\lim _{r \rightarrow r_{1}^{+}} m^{\prime}(r)$ and $\lim _{r \rightarrow r_{2}^{-}} m^{\prime}(r)>\lim _{r \rightarrow r_{2}^{+}} m^{\prime}(r)$

Proof of Proposition 2. The monopolistic bank revenue is $R(m)=(1+r(m)) m$, where $r=r(m)$ is the (inverse) demand for loans. $m^{*}>0$ is a solution for the monopolistic bank if and only if $M R(m) \geq M C(m)=c$ for all $m<m^{*}$ and $M R(m) \leq M C(m)=c$ for all $m>m^{*}$, where $M R$ and $M C$ are the marginal revenue and the marginal cost of the monopolist respectively.

The marginal revenue has two discontinuities. In $m_{2}$ we have

$$
\begin{aligned}
& M R_{-}\left(m_{2}\right)=r_{-}{ }^{\prime}\left(m_{2}\right) m_{2}+1+r_{2}=\frac{m_{2}}{m_{+}{ }^{\prime}\left(r_{2}\right)}+1+r_{2}=\frac{u^{\prime \prime}\left(w_{0}+m_{2} / p_{0}\right)}{\lambda p_{0}^{2}} m_{2}+1+r_{2} \\
& M R_{+}\left(m_{2}\right)=r_{+}{ }^{\prime}\left(m_{2}\right) m_{2}+1+r_{2}=\frac{m_{2}}{m_{-}{ }^{\prime}\left(r_{2}\right)}+1+r_{2}=\frac{(1+\delta) u^{\prime \prime}\left(w_{0}+m_{2} / p_{0}\right)}{\lambda p_{0}^{2}} m_{2}+1+r_{2}
\end{aligned}
$$

So, if $c$ belongs to the interval $I_{2}=\left(M R_{+}\left(m_{2}\right), M R_{-}\left(m_{2}\right)\right)$, then the equilibrium interest rate is $m^{*}=m_{2}$. In $m_{1}$ the behavior is qualitatively different. If we calculate the marginal revenue in that point we will have

$$
\begin{aligned}
& M R_{-}\left(m_{1}\right)=r_{-}{ }^{\prime}\left(m_{1}\right) m_{1}+1+r_{1}=\frac{m_{1}}{m_{+}{ }^{\prime}\left(r_{1}\right)}+1+r_{1}=\frac{(1+\delta) u "\left(w_{0}+m_{1} / p_{0}\right)}{\lambda p_{0}^{2}} m_{1}+1+r_{1} \\
& M R_{+}\left(m_{1}\right)=r_{+}{ }^{\prime}\left(m_{1}\right) m_{1}+1+r_{1}=\frac{m_{1}}{m_{-}{ }^{\prime}\left(r_{1}\right)}+1+r_{1}=\frac{u^{\prime \prime}\left(w_{0}+m_{1} / p_{0}\right)}{\lambda p_{0}^{2}} m_{1}+1+r_{1}
\end{aligned}
$$

Therefore $M R_{-}\left(m_{1}\right)<M R_{+}\left(m_{1}\right)$, thus, if $c \in I_{1}=\left(M R_{-}\left(m_{1}\right), M R_{+}\left(m_{1}\right)\right)$, then $m^{*}=m_{1}$ becomes a relative minimum with two relative maximums around it. 